Ferrata Storti Foundation

\title{
Rapid growth is a dominant predictor of hepcidin suppression and declining ferritin in Gambian infants
}

Haematologica 2019

Volume 104(8):1542-1553

\section{Andrew E. Armitage,${ }^{1 *}$ Schadrac C. Agbla,${ }^{2 *}$ Modupeh Betts, ${ }^{3}$ Ebrima A. Sise,${ }^{3}$ Momodou W. Jallow, ${ }^{3}$ Ellen Sambou, ${ }^{4}$ Bakary Darboe, ${ }^{3}$ Archibald Worwui, ${ }^{3}$ George M. Weinstock, ${ }^{5}$ Martin Antonio, ${ }^{4}$ Sant-Rayn Pasricha, ${ }^{1,6,7}$ Andrew M. Prentice, ${ }^{3}$ Hal Drakesmith, ${ }^{1,8}$ Momodou K. Darboe ${ }^{3, * *}$ and Brenda Anna Kwambana-Adams ${ }^{4,9, \star \star}$}

${ }^{1}$ MRC Human Immunology Unit, MRC Weatherall Institute of Molecular Medicine, University of Oxford, Oxford, UK; ${ }^{2}$ Faculty of Epidemiology and Population Health, London School of Hygiene and Tropical Medicine, London, UK; ${ }^{3} \mathrm{MRC}$ Unit The Gambia at the London School of Hygiene and Tropical Medicine, Banjul, The Gambia, Africa; ${ }^{4} \mathrm{WHO}$ Collaborating Center for New Vaccines Surveillance, MRC Unit The Gambia at the London School of Hygiene and Tropical Medicine, Banjul, The Gambia, Africa; ${ }^{5}$ The Jackson Laboratory for Genomic Medicine, Farmington, CT, USA; ${ }^{6}$ Walter and Eliza Hall Institute for Medical Research, Melbourne, VIC, Australia; ${ }^{7}$ Department of Medical Biology, The University of Melbourne, VIC, Melbourne, Australia; ${ }^{8} \mathrm{Haematology}$ Theme, Oxford Biomedical Research Centre, Oxford, UK and ${ }^{9}$ NIHR Global Health Research Unit on Mucosal Pathogens, Division of Infection and Immunity, University College London, London, UK

${ }^{\star}$ Contributed equally to this work. ${ }^{*}$ Contributed equally as senior co-authors.

\section{Correspondence:}

ANDREW E. ARMITAGE/BRENDA ANNA KWAMBANA-ADAMS andrew.armitage@imm.ox.ac.uk/ rekgbak@ucl.ac.uk

Received: October 25, 2018.

Accepted: January 31, 2019.

Pre-published: February 7, 2019.

doi:10.3324/haematol.2018.210146

Check the online version for the most updated information on this article, online supplements, and information on authorship \& disclosures: www.haematologica.org/content/104/8/1542

(C)2019 Ferrata Storti Foundation

Material published in Haematologica is covered by copyright. All rights are reserved to the Ferrata Storti Foundation. Use of published material is allowed under the following terms and conditions:

https://creativecommons.org/licenses/by-nc/4.0/legalcode. Copies of published material are allowed for personal or internal use. Sharing published material for non-commercial purposes is subject to the following conditions:

https://creativecommons.org/licenses/by-nc/4.0/leǵalcode, sect. 3. Reproducing and sharing published material for commercial purposes is not allowed without permission in writing from the publisher.

\section{ABSTRACT}

Tr ron deficiency and iron deficiency anemia are highly prevalent in low-income countries, especially among young children. Hepcidin is the major regulator of systemic iron homeostasis. It controls dietary iron absorption, dictates whether absorbed iron is made available in circulation for erythropoiesis and other iron-demanding processes, and predicts response to oral iron supplementation. Understanding how hepcidin is itself regulated is therefore important, especially in young children. We investigated how changes in iron-related parameters, inflammation and infection status, seasonality, and growth influenced plasma hepcidin and ferritin concentrations during infancy using longitudinal data from two birth cohorts of infants in rural Gambia ( $\mathrm{n}=114$ and $\mathrm{n}=193$ ). This setting is characterized by extreme seasonality, prevalent childhood anemia, undernutrition, and frequent infection. Plasma was collected from infants at birth and at regular intervals, up to 12 months of age. Hepcidin, ferritin and plasma iron concentrations declined markedly during infancy, with reciprocal increases in soluble transferrin receptor and transferrin concentrations, indicating declining iron stores and increasing tissue iron demand. In cross-sectional analyses at 5 and 12 months of age, we identified expected relationships of hepcidin with iron and inflammatory markers, but also observed significant negative associations between hepcidin and antecedent weight gain. Correspondingly, longitudinal fixed effects modeling demonstrated weight gain to be the most notable dynamic predictor of decreasing hepcidin and ferritin through infancy across both cohorts. Infants who grow rapidly in this setting are at particular risk of depletion of iron stores, but since hepcidin concentrations decrease with weight gain, they may also be the most responsive to oral iron interventions. 


\section{Introduction}

Iron deficiency anemia (IDA) affected 1.24 billion people and was the most common cause of Years Lived with Disability (YLD) in low- and low-middle income countries in 2016. Iron deficiency (ID) and anemia disproportionately affect young children in such socio-economic settings. ${ }^{2}$ Beyond anemia, ID during infancy is linked to impaired cognitive and behavioral development, potentially yielding irreversible long-term individual and societal impacts., ${ }^{3,4}$

Neonates are born with a maternal iron endowment that is initially largely contained within hemoglobin and influenced by birthweight, gestational age, and the timing and method of cord clamping. ${ }^{5.7}$ In healthy term infants, this birth endowment meets the iron needs of blood volume expansion, brain development and tissue accretion for several months, compensating for the very low level of iron in breast milk; ${ }^{5}$ after this, complementary feeding must supply iron.$^{6.9}$ Iron-poor diets and high infection burdens, when combined with the significant physiological iron demands of growth and development during infancy, render young LMIC children especially vulnerable to ID/IDA.

The hepatic hormone hepcidin regulates systemic iron handling. ${ }^{10} \mathrm{Hepcidin}$ inhibits the cellular iron exporter ferroportin, preventing iron recycling by erythrophagocytic macrophages and dietary iron uptake through enterocytes. ${ }^{11}$ Hepcidin induction by iron prevents iron overload, while its production during inflammation/infection generates an acute anti-infective hypoferremia: ${ }^{12,13}$ moreover, chronically raised hepcidin causes ID and IDA, ${ }^{14}$ and chronic ID and IDA can protect against malaria. ${ }^{15-17}$ In contrast, hepcidin suppression during iron demand, for example via erythroferrone activity in response to erythropoietic stress, increases serum iron availability ${ }^{18}$ In African preschool children, hepcidin reflects iron status and effectively predicts utilization of orally administered iron. ${ }^{19,20}$ However, its regulation during the first year of life remains poorly characterized. ${ }^{6}$

The Gambia is an African country characterized by high burdens of infection, undernutrition and anemia, together with extreme seasonality, all of which have the potential to influence iron control through effects on hepcidin. ${ }^{21}$ In the clearly demarcated wet season, nutritional availability and quality deteriorate, infections are more prevalent, and growth faltering is more prominent. Here, we used two longitudinal birth cohort studies from rural communities in The Gambia to investigate how relative changes in iron, infection and inflammation, erythropoietic drive, seasonality, and growth rate predict changes in hepcidin and the iron stores marker ferritin during the first year of life.

\section{Methods}

Details of cohort characteristics, methods and statistics are presented in the Online Supplementary Appendix and Online Supplementary Tables S1 and S2.

\section{Cohorts}

We obtained biochemical, anthropometric and infection data at serial time points [birth (cord blood), 2, 5, 9 (VA cohort only) and 12 months of age] from two rural birth-cohort studies in The Gambia, West Africa:
- VPM study: Vaccination and Paediatric Microbiome (VPM) study. Conducted in the Western Region; March 2013-September 2015; $\mathrm{n}=114$;

- VA study: a vitamin A supplementation randomized controlled trial. ${ }^{22}$ Conducted in the West Kiang Region; September 2001-October 2004; $\mathrm{n}=193$.

\section{Laboratory analysis}

Ferritin, plasma iron, soluble transferrin receptor (sTfR), $\alpha(1)$ acid glycoprotein (AGP), C-reactive protein (CRP), transferrin (VPM only), and hemoglobin (VA only) concentrations were measured by automated analyzers. Hepcidin was measured by manual ELISA (Bachem/Peninsula Laboratories, San Carlos, CA, USA). ${ }^{21}$

\section{Definitions}

Anthropometric Z-scores (World Health Organization child growth standards): generated using STATA package zscore $06^{23}$ Wet season: July-October. Weaning: first recorded occurrence of any feeding other than exclusive breastfeeding. Positive recent infection: occurrence within the previous four weeks of ear infection, chest infection, meningitis/sepsis, or other symptoms associated with infection (including fever, diarrhea, vomiting), or if antibiotics were administered within the previous two weeks (VPM); or of diarrhea, vomiting, fever, cough or clinic attendance (VA). Iron deficiency (ID): ferritin $<12 \mu \mathrm{g} / \mathrm{L}$ or ferritin $<30 \mu \mathrm{g} / \mathrm{L}$ if $\mathrm{CRP}>5 \mathrm{mg} / \mathrm{L}$; anemia: $\mathrm{Hb}<11 \mathrm{~g} / \mathrm{dL}$; inflammation: $\mathrm{CRP}>5 \mathrm{mg} / \mathrm{L}$; iron deficiency anemia (IDA): anemia in the presence of ID. ${ }^{21}$

\section{Statistical analysis}

RStudio (v1.1), Stata14 (Statacorp-LP), R (www.r-project.org) and Prism7 (GraphPad Software) were used for statistical analysis and graphics.

To address the potential bias that may arise when deriving parameter estimates in the presence of missing data, ${ }^{24,25}$ as discussed in detail in the Online Supplementary Appendix, we implemented multiple imputation by chained equations (MICE) to generate 100 independent datasets with missing data imputed; ${ }^{26}$ after analyzing imputed datasets, estimates were pooled using Rubin's rules. $^{27}$ Continuous variables were log10-transformed prior to multiple imputation. Subsequent analyses were performed on both imputed datasets and original pre-imputation datasets; the latter are shown in the Online Supplementary Appendix.

Analyses comprised:

- univariate correlations with hepcidin and ferritin, computing Pearson correlation coefficients;

- multivariate cross-sectional analyses at five and 12 months of age incorporating parameters returning $P<0.2$ in univariate analysis; Seemingly Unrelated Regression analysis, ${ }^{28}$ enabled simultaneous modeling of the correlated outcomes, hepcidin and ferritin;

- longitudinal panel fixed effects models [estimating DriscollKraay standard errors ${ }^{29}$ using Stata command xtscc $(\mathrm{st} 0128)^{30}$ ] to enable investigation of how within-infant changes over time in time-variant explanatory variables predict changes in hepcidin and ferritin addressing any confounding induced by time-invariant characteristics (e.g. sex, genotype, ethnicity), whether measured or unmeasured; to visualize relative effect sizes, data were standardized, fixed effects models were refitted, and forest plots were generated.

\section{Ethical considerations}

The Gambia Government/Medical Research Council (MRC) Joint Ethics Committee approved both studies (VPM: SCC1315; VA: SCC844); VA was also approved by the Ethics Committee of the London School of Hygiene and Tropical Medicine (LSHTM), Banjul, The Gambia. All participants were recruited via approved 
protocols; parents and/or legal guardians gave written informed consent for infants. Studies were performed in accordance with the Declaration of Helsinki.

\section{Results}

Decline in hepcidin and iron status through infancy

High plasma concentrations of hepcidin and ferritin in the absence of inflammation suggest that the majority of infants were iron replete at birth and up to two months of age (Figure $1 \mathrm{~A}$ and $\mathrm{B})$. Hepcidin concentrations declined from two to 12 months of age in both VPM and VA infant cohorts. In both cohorts, declines were most marked in males born in the lower birthweight group (Figure 1A). Similar patterns of decline were observed for ferritin, indicating rapid depletion of iron stores through infancy (Figure 1B). The decline in hepcidin and ferritin occurred
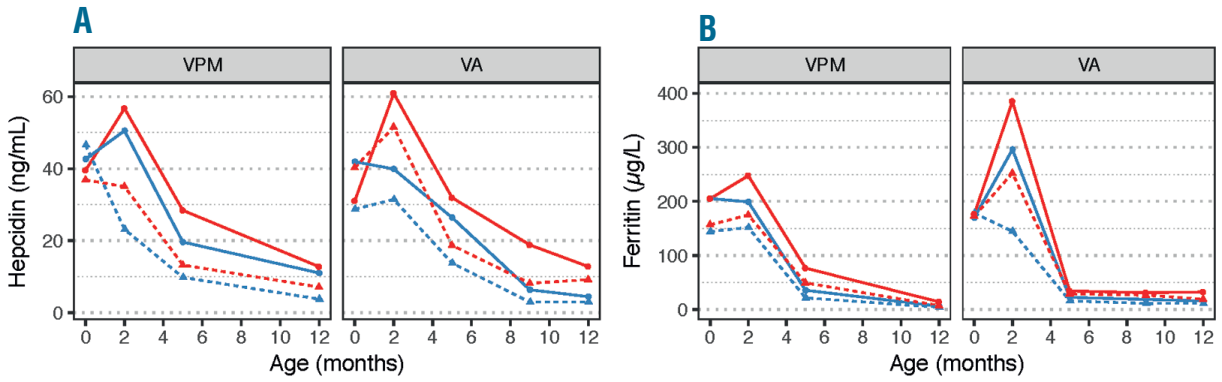

C
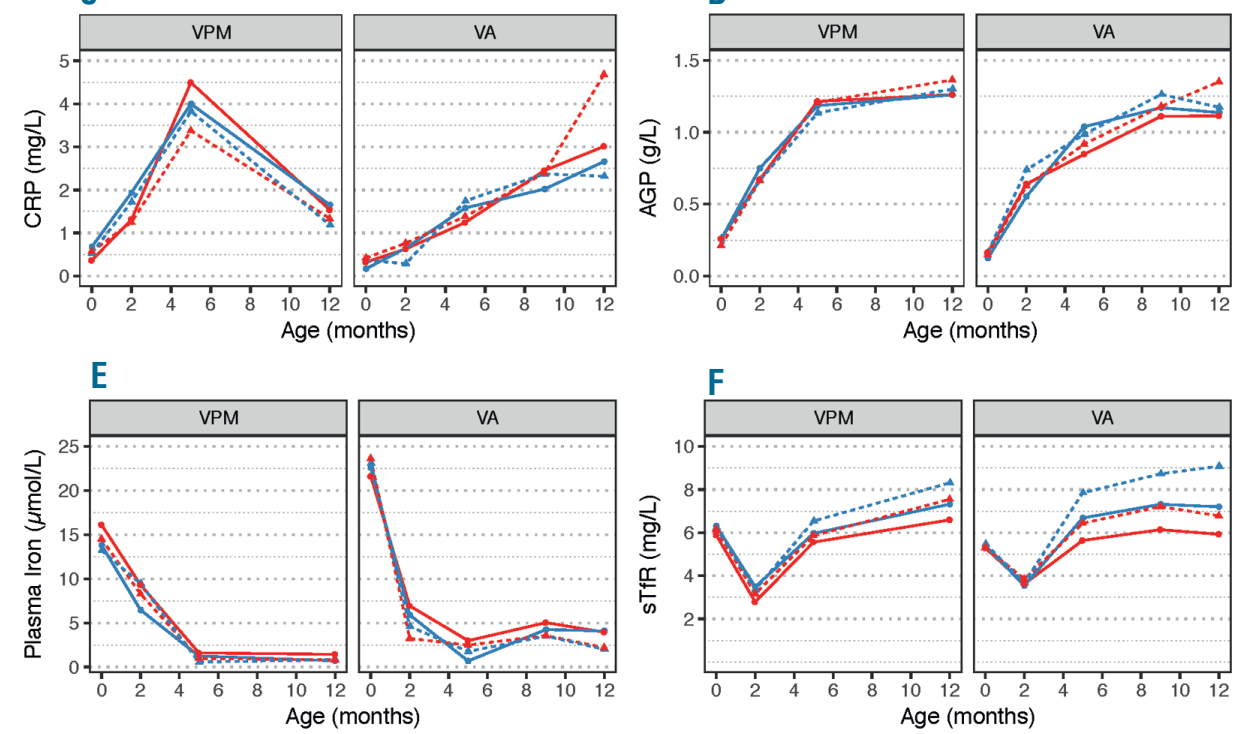

G
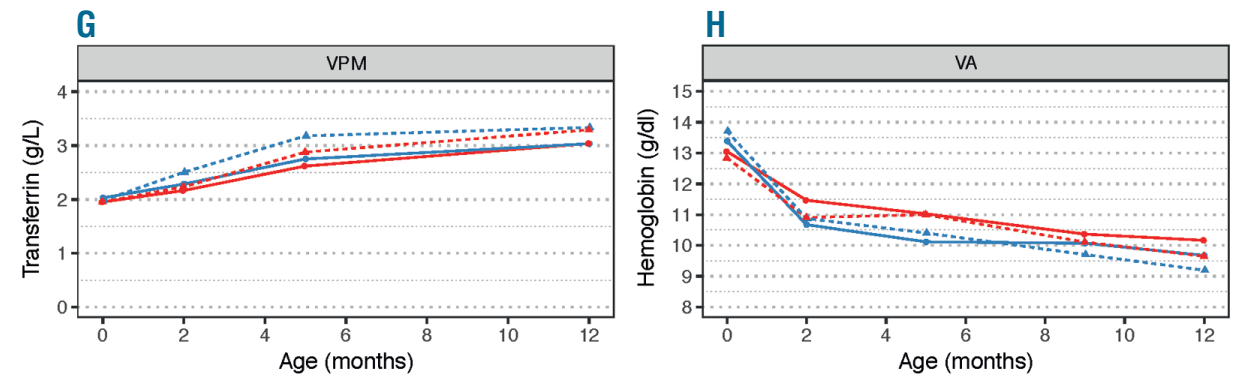

Sex $\rightarrow$ Female $\rightarrow$ Male

Birthweight $\rightarrow$ Birth-WAZ $>-0.5 \cdots$ Birth-WAZ $\leq-0.5$

Figure 1. Changes in hepcidin and iron/inflammatory biomarkers across the first year of life in Gambian infants. Plots summarize changes in (A) hepcidin, (B) ferritin, (C) C-reactive protein (CRP), (D) $\alpha(1)$-acid glycoprotein (AGP), (E) plasma iron, (F) soluble transferrin receptor (sTfR), and (G) transferrin (VPM only), and (H) hemoglobin (VA cohort) occurring across the first year of life in two cohorts of Gambian infants, VPM (left panels) and VA (right panels). Plots depict mean for cross-sectional data at each time point, stratifying by sex (male: blue; female: red) and birthweight group [World Health Organization weight-for-age z-score (WAZ) -0.5: above -0.5: solid line, or below -0.5: dashed line], summarizing 100 datasets in which any missing data was imputed by multiple imputation, combined using Rubin's combination rules, as described in detail in the Methods section and the Online Supplementary Methods. 95\% Confidence Intervals are omitted for clarity, but are given in Online Supplementary Table S4. Equivalent plots based on the original data prior to multiple imputation are shown in Online Supplementary Figure S1. VPM: Vaccination and Paediatric Microbiome study; VA: a vitamin A supplementation randomized controlled trial. ${ }^{22}$ 
despite higher inflammatory burden later in infancy, reflected by increased CRP and AGP concentrations (Figure 1C and D). Plasma iron showed the most striking decline of any iron biomarker, with concentrations falling from birth in all infant groups, irrespective of sex or birthweight, to concentrations well below normal expected values for iron replete young children (typically $>10$ $\mu \mathrm{mol} / \mathrm{L})^{31}$ by five months of age in both cohorts (Figure 1E). Concentrations of sTfR, commonly used as a surrogate for erythropoietic iron demand, were reduced at two months of age (until when erythropoietic output is likely to have been $l \mathrm{w}^{32}$ ) in both cohorts. Erythropoietic activity typically increases from around this age, and is likely influenced by the declining plasma iron availability; consistent with this, sTfR and transferrin concentrations were both elevated by 12 months of age, again most notably in lower birthweight males (Figure 1F and G). Accordingly, this group had the lowest hemoglobin concentration by 12 months of age (Figure $1 \mathrm{H}$ ), and by this time the population had experienced a heavy burden of iron deficiency and anemia: $67.7 \%$ (95\%CI: $56.2-79.2 \%$ ) and $36.4 \%$ (95\% CI: $25.6-47.3 \%$ ) of females, and $77.8 \%(95 \% \mathrm{CI}$ : $65.6-90.0 \%$ ) and $45.3 \%$ (95\% CI: $34.5-56.1 \%$ ) of males in VPM and VA, respectively, were classified as iron deficient at 1 year of age; $86.5 \%$ (95\% CI: $79.5-93.5 \%$ ) of females and $93.1 \%$ (95\% CI: 87.8-98.4\%) of males were classified as anemic in VA (in which hemoglobin was measured) (Online Supplementary Table S3).

Associations with hepcidin and ferritin concentrations at five and $\mathbf{1 2}$ months of age: cross-sectional analyses

To explore the relationships of hepcidin and ferritin with other variables during infancy, we next performed cross-sectional univariable analyses at month 5 (the time

Table 1. Cross-sectional correlations between hepcidin, ferritin, and explanatory variables in infants at five months of age.

\begin{tabular}{|c|c|c|c|c|c|}
\hline \multirow{2}{*}{$\begin{array}{c}\text { MONTH } 5 \\
\text { Summary of } 100 \\
\text { imputed datasets }\end{array}$} & \multirow[b]{2}{*}{ Statistic } & \multicolumn{2}{|c|}{ VPM study } & \multicolumn{2}{|c|}{ VA study } \\
\hline & & Hepcidin & Ferritin & Hepcidin & Ferritin \\
\hline Ferritin & $\begin{array}{l}\mathrm{r} \\
\mathrm{p}\end{array}$ & $\begin{array}{r}0.618 \\
<0.001 \\
\end{array}$ & & $\begin{array}{l}0.333 \\
0.001 \\
\end{array}$ & \\
\hline Transferrin & $\begin{array}{l}\mathrm{r} \\
\mathrm{p}\end{array}$ & $\begin{array}{l}-0.624 \\
<0.001 \\
\end{array}$ & $\begin{array}{l}-0.588 \\
<0.001\end{array}$ & & \\
\hline Plasma iron & $\begin{array}{l}\mathrm{r} \\
\mathrm{p}\end{array}$ & $\begin{array}{c}-0.131 \\
0.182\end{array}$ & $\begin{array}{c}-0.074 \\
0.451\end{array}$ & $\begin{array}{l}0.011 \\
0.909\end{array}$ & $\begin{array}{c}0.16 \\
0.132\end{array}$ \\
\hline sTfR & $\begin{array}{l}\mathrm{r} \\
\mathrm{p}\end{array}$ & $\begin{array}{l}-0.349 \\
<0.001\end{array}$ & $\begin{array}{r}-0.321 \\
0.001 \\
\end{array}$ & $\begin{array}{l}-0.283 \\
0.005 \\
\end{array}$ & $\begin{array}{l}-0.35 \\
<0.001\end{array}$ \\
\hline $\mathbf{H b}$ & $\begin{array}{l}\mathrm{r} \\
\mathrm{p}\end{array}$ & & & $\begin{array}{l}0.068 \\
0.452\end{array}$ & $\begin{array}{l}0.207 \\
0.032\end{array}$ \\
\hline CRP & $\begin{array}{l}\mathrm{r} \\
\mathrm{p}\end{array}$ & $\begin{array}{l}0.295 \\
0.013 \\
\end{array}$ & $\begin{array}{l}0.209 \\
0.069 \\
\end{array}$ & $\begin{array}{c}0.184 \\
0.03 \\
\end{array}$ & $\begin{array}{l}-0.06 \\
0.496 \\
\end{array}$ \\
\hline AGP & $\begin{array}{l}\mathrm{r} \\
\mathrm{p}\end{array}$ & $\begin{array}{l}0.244 \\
0.023 \\
\end{array}$ & $\begin{array}{c}0.22 \\
0.032 \\
\end{array}$ & $\begin{array}{l}0.132 \\
0.169 \\
\end{array}$ & $\begin{array}{l}-0.007 \\
0.937 \\
\end{array}$ \\
\hline $\begin{array}{l}\text { Infection reported in } \\
\text { previous } 4 \text { weeks }\end{array}$ & r & $\begin{array}{l}0.163 \\
0.113 \\
\end{array}$ & $\begin{array}{c}0.117 \\
0.24\end{array}$ & $\begin{array}{l}-0.062 \\
0.443 \\
\end{array}$ & $\begin{array}{c}-0.071 \\
0.441 \\
\end{array}$ \\
\hline $\begin{array}{c}\text { Sample taken in wet } \\
\text { season (Jul-Oct) }\end{array}$ & $\begin{array}{l}\mathrm{r} \\
\mathrm{p}\end{array}$ & $\begin{array}{l}0.196 \\
0.042 \\
\end{array}$ & $\begin{array}{l}0.043 \\
0.656 \\
\end{array}$ & $\begin{array}{l}0.035 \\
0.687 \\
\end{array}$ & $\begin{array}{c}-0.119 \\
0.227 \\
\end{array}$ \\
\hline Sex & $\begin{array}{l}\mathrm{r} \\
\mathrm{p}\end{array}$ & $\begin{array}{c}-0.138 \\
0.151\end{array}$ & $\begin{array}{l}-0.282 \\
0.003\end{array}$ & $\begin{array}{c}-0.094 \\
0.291\end{array}$ & $\begin{array}{c}-0.162 \\
0.093\end{array}$ \\
\hline $\begin{array}{c}\text { Weight-for-Age } Z \\
\text { score at birth }\end{array}$ & $\begin{array}{l}\mathrm{r} \\
\mathrm{p}\end{array}$ & $\begin{array}{c}0.38 \\
<0.001\end{array}$ & $\begin{array}{l}0.181 \\
0.061\end{array}$ & $\begin{array}{l}0.233 \\
0.004 \\
\end{array}$ & $\begin{array}{l}0.065 \\
0.494\end{array}$ \\
\hline Weight at 5 months & $\begin{array}{l}\mathrm{r} \\
\mathrm{p}\end{array}$ & $\begin{array}{l}-0.103 \\
0.327 \\
\end{array}$ & $\begin{array}{l}-0.237 \\
0.022 \\
\end{array}$ & $\begin{array}{l}-0.188 \\
0.019 \\
\end{array}$ & $\begin{array}{c}-0.182 \\
0.04 \\
\end{array}$ \\
\hline Length at 5 months & $\begin{array}{l}\mathrm{r} \\
\mathrm{p}\end{array}$ & $\begin{array}{l}0.004 \\
0.971\end{array}$ & $\begin{array}{c}-0.027 \\
0.781\end{array}$ & $\begin{array}{c}-0.125 \\
0.113\end{array}$ & $\begin{array}{c}-0.148 \\
0.087\end{array}$ \\
\hline $\begin{array}{l}\text { Head Circ. at } 5 \\
\text { months }\end{array}$ & r & $\begin{array}{l}0.109 \\
0.274\end{array}$ & $\begin{array}{c}-0.003 \\
0.974\end{array}$ & $\begin{array}{l}-0.095 \\
0.248\end{array}$ & $\begin{array}{c}-0.209 \\
0.017\end{array}$ \\
\hline $\begin{array}{c}\text { Weight gain between } \\
0-5 \text { months }\end{array}$ & $\begin{array}{l}\mathrm{r} \\
\mathrm{p}\end{array}$ & $\begin{array}{l}-0.424 \\
<0.001\end{array}$ & $\begin{array}{l}-0.363 \\
<0.001\end{array}$ & $\begin{array}{l}-0.372 \\
<0.001\end{array}$ & $\begin{array}{c}-0.211 \\
0.019\end{array}$ \\
\hline $\begin{array}{c}\text { Length gain between } \\
0-5 \text { months }\end{array}$ & $\begin{array}{l}r \\
\mathrm{p}\end{array}$ & $\begin{array}{c}-0.243 \\
0.017\end{array}$ & $\begin{array}{l}-0.167 \\
0.096\end{array}$ & $\begin{array}{l}-0.192 \\
0.013\end{array}$ & $\begin{array}{c}-0.119 \\
0.16\end{array}$ \\
\hline $\begin{array}{c}\text { Head Circ. gain } \\
\text { between } 0-5 \text { months }\end{array}$ & r & $\begin{array}{l}-0.182 \\
0.06\end{array}$ & $\begin{array}{l}-0.19 \\
0.049\end{array}$ & $\begin{array}{l}-0.222 \\
0.011\end{array}$ & $\begin{array}{l}-0.15 \\
0.116\end{array}$ \\
\hline
\end{tabular}

Data summarize 100 datasets in which any missing data were imputed using multiple imputation as described in detail in the Methods section and the Online Supplementary Appendix. Infection was coded as "no infection=0" and "occurrence of infection=1'; Season was coded as "dry season (November-June)=0" and "wet season (July-October)=1", Sex was coded as "female=0" and "male=1"; Head Circ.: head circumference. " $r$ " denotes the Pearson correlation coefficient. Significance level is highlighted with blue shading. Dark blue: $P<0.001$; mid-blue: $P<0.01$; light blue: $P<0.05$. 
point nearest typical weaning) (Table 1) and at month 12 (Table 2). There were significant correlations in both cohorts of hepcidin and ferritin with sTfR, transferrin (assessed in VPM only), CRP and AGP, suggesting hepcidin is regulated similarly in infants compared to older children/adults. ${ }^{21}$

Lower birthweight correlated significantly with lower hepcidin concentrations at five and 12 months in VPM, and at five months in VA, likely reflecting how individuals born with smaller iron endowments are at greater risk of iron depletion during infancy. ${ }^{8}$ However, we also found strong evidence that the extent of antecedent weight gain (especially weight gain between 0 and 5 months of age) was negatively associated with the hepcidin and ferritin concentrations observed at both five and 12 months of age (Tables 1 and 2). In contrast, there were no significant associations of hepcidin and ferritin concentrations at any time point with subsequent weight gain in either cohort (data not shown).

We then constructed multivariate models to investigate

Table 2. Cross-sectional correlations between hepcidin, ferritin, and explanatory variables in infants at 12 months of age.

\begin{tabular}{|c|c|c|c|c|c|}
\hline \multirow{2}{*}{$\begin{array}{c}\text { MONTH } 12 \\
\text { Summary of } 100 \\
\text { imputed datasets }\end{array}$} & \multicolumn{3}{|c|}{ VPM study } & \multicolumn{2}{|c|}{ VA study } \\
\hline & Statistic & Hepcidin & Ferritin & Hepcidin & Ferritin \\
\hline Ferritin & $\begin{array}{l}\mathrm{r} \\
\mathrm{p}\end{array}$ & $\begin{array}{c}0.46 \\
<0.001\end{array}$ & & $\begin{array}{c}0.492 \\
<0.001\end{array}$ & \\
\hline Transferrin & $\begin{array}{l}\mathrm{r} \\
\mathrm{p}\end{array}$ & $\begin{array}{l}-0.476 \\
<0.001\end{array}$ & $\begin{array}{l}-0.43 \\
<0.001\end{array}$ & & \\
\hline Plasma iron & $\begin{array}{l}\mathrm{r} \\
\mathrm{p}\end{array}$ & $\begin{array}{l}0.07 \\
0.505 \\
\end{array}$ & $\begin{array}{l}0.047 \\
0.633 \\
\end{array}$ & $\begin{array}{l}0.03 \\
0.751 \\
\end{array}$ & $\begin{array}{c}0.15 \\
0.105 \\
\end{array}$ \\
\hline sTfR & r & $\begin{array}{l}-0.414 \\
<0.001\end{array}$ & $\begin{array}{c}-0.209 \\
0.036\end{array}$ & $\begin{array}{l}-0.441 \\
<0.001\end{array}$ & $\begin{array}{l}-0.472 \\
<0.001 \\
\end{array}$ \\
\hline $\mathbf{H b}$ & $\begin{array}{l}\mathrm{r} \\
\mathrm{p}\end{array}$ & & & $\begin{array}{l}0.165 \\
0.034\end{array}$ & $\begin{array}{l}0.167 \\
0.034\end{array}$ \\
\hline CRP & $\begin{array}{l}\mathrm{r} \\
\mathrm{p}\end{array}$ & $\begin{array}{l}0.292 \\
0.005 \\
\end{array}$ & $\begin{array}{l}0.201 \\
0.043 \\
\end{array}$ & $\begin{array}{l}0.278 \\
0.002 \\
\end{array}$ & $\begin{array}{c}0.2 \\
0.029 \\
\end{array}$ \\
\hline AGP & $\begin{array}{l}\mathrm{r} \\
\mathrm{p}\end{array}$ & $\begin{array}{l}0.324 \\
0.004\end{array}$ & $\begin{array}{l}0.258 \\
0.012\end{array}$ & $\begin{array}{l}0.189 \\
0.039\end{array}$ & $\begin{array}{c}0.14 \\
0.156\end{array}$ \\
\hline $\begin{array}{l}\text { Infection reported in } \\
\text { previous } 4 \text { weeks }\end{array}$ & $\begin{array}{l}\mathrm{r} \\
\mathrm{p}\end{array}$ & $\begin{array}{l}0.225 \\
0.024 \\
\end{array}$ & $\begin{array}{c}0.156 \\
0.11 \\
\end{array}$ & $\begin{array}{c}0.09 \\
0.233 \\
\end{array}$ & $\begin{array}{c}0 \\
0.996 \\
\end{array}$ \\
\hline $\begin{array}{c}\text { Sample taken in wet } \\
\text { season (Jul-Oct) }\end{array}$ & $\begin{array}{l}\mathrm{r} \\
\mathrm{p}\end{array}$ & $\begin{array}{l}0.186 \\
0.051 \\
\end{array}$ & $\begin{array}{l}0.053 \\
0.575 \\
\end{array}$ & $\begin{array}{l}0.23 \\
0.002 \\
\end{array}$ & $\begin{array}{l}0.136 \\
0.075 \\
\end{array}$ \\
\hline Sex & $\begin{array}{l}\mathrm{r} \\
\mathrm{p}\end{array}$ & $\begin{array}{c}-0.111 \\
0.267 \\
\end{array}$ & $\begin{array}{c}-0.178 \\
0.063\end{array}$ & $\begin{array}{l}-0.344 \\
<0.001\end{array}$ & $\begin{array}{l}-0.207 \\
0.007 \\
\end{array}$ \\
\hline $\begin{array}{c}\text { Weight-for-Age } Z \\
\text { score at birth }\end{array}$ & $\begin{array}{l}\mathrm{r} \\
\mathrm{p}\end{array}$ & $\begin{array}{l}0.266 \\
0.008\end{array}$ & $\begin{array}{l}0.036 \\
0.713 \\
\end{array}$ & $\begin{array}{l}0.131 \\
0.081 \\
\end{array}$ & $\begin{array}{c}0.17 \\
0.025 \\
\end{array}$ \\
\hline Weight at 12 months & $\begin{array}{l}\mathrm{r} \\
\mathrm{p}\end{array}$ & $\begin{array}{l}-0.06 \\
0.556\end{array}$ & $\begin{array}{c}-0.098 \\
0.311\end{array}$ & $\begin{array}{c}-0.243 \\
0.001\end{array}$ & $\begin{array}{c}-0.179 \\
0.018\end{array}$ \\
\hline Length at 12 months & $\begin{array}{l}\mathrm{r} \\
\mathrm{p}\end{array}$ & $\begin{array}{c}-0.128 \\
0.213 \\
\end{array}$ & $\begin{array}{r}-0.216 \\
0.027 \\
\end{array}$ & $\begin{array}{r}-0.224 \\
0.003 \\
\end{array}$ & $\begin{array}{l}-0.176 \\
0.019 \\
\end{array}$ \\
\hline $\begin{array}{c}\text { Head Circumference } \\
\text { at } 12 \text { months }\end{array}$ & $\begin{array}{l}\mathrm{r} \\
\mathrm{p}\end{array}$ & $\begin{array}{r}-0.029 \\
0.764 \\
\end{array}$ & $\begin{array}{c}-0.028 \\
0.768 \\
\end{array}$ & $\begin{array}{c}-0.128 \\
0.089\end{array}$ & $\begin{array}{c}-0.125 \\
0.1\end{array}$ \\
\hline $\begin{array}{c}\text { Weight gain between } \\
0-12 \text { months }\end{array}$ & $\begin{array}{l}\mathrm{r} \\
\mathrm{p}\end{array}$ & $\begin{array}{l}-0.275 \\
0.005\end{array}$ & $\begin{array}{c}-0.102 \\
0.29 \\
\end{array}$ & $\begin{array}{c}-0.3 \\
<0.001 \\
\end{array}$ & $\begin{array}{l}-0.288 \\
<0.001 \\
\end{array}$ \\
\hline $\begin{array}{c}\text { Weight gain between } \\
0-5 \text { months }\end{array}$ & $\begin{array}{l}\mathrm{r} \\
\mathrm{p}\end{array}$ & $\begin{array}{l}-0.344 \\
<0.001\end{array}$ & $\begin{array}{c}-0.196 \\
0.038\end{array}$ & $\begin{array}{c}-0.247 \\
0.001\end{array}$ & $\begin{array}{l}-0.245 \\
0.002\end{array}$ \\
\hline $\begin{array}{c}\text { Weight gain between } \\
5-12 \text { months } \\
\end{array}$ & $\begin{array}{l}\mathrm{r} \\
\mathrm{p} \\
\end{array}$ & $\begin{array}{l}0.096 \\
0.344 \\
\end{array}$ & $\begin{array}{c}0.125 \\
0.2 \\
\end{array}$ & $\begin{array}{c}-0.123 \\
0.11 \\
\end{array}$ & $\begin{array}{l}-0.102 \\
0.185 \\
\end{array}$ \\
\hline $\begin{array}{c}\text { Length gain between } \\
0-12 \text { months }\end{array}$ & $\begin{array}{l}\mathrm{r} \\
\mathrm{p}\end{array}$ & $\begin{array}{c}-0.255 \\
0.01 \\
\end{array}$ & $\begin{array}{r}-0.169 \\
0.084 \\
\end{array}$ & $\begin{array}{c}-0.2 \\
0.012 \\
\end{array}$ & $\begin{array}{l}-0.212 \\
0.005 \\
\end{array}$ \\
\hline $\begin{array}{c}\text { Length gain between } \\
0-5 \text { months }\end{array}$ & $\begin{array}{l}\mathrm{r} \\
\mathrm{p}\end{array}$ & $\begin{array}{c}-0.216 \\
0.028\end{array}$ & $\begin{array}{c}-0.134 \\
0.174\end{array}$ & $\begin{array}{c}-0.195 \\
0.015\end{array}$ & $\begin{array}{c}-0.197 \\
0.011\end{array}$ \\
\hline $\begin{array}{c}\text { Length gain between } \\
5-12 \text { months } \\
\end{array}$ & $\begin{array}{l}\mathrm{r} \\
\mathrm{p}\end{array}$ & $\begin{array}{c}-0.069 \\
0.521 \\
\end{array}$ & $\begin{array}{r}-0.067 \\
0.509 \\
\end{array}$ & $\begin{array}{r}-0.037 \\
0.621 \\
\end{array}$ & $\begin{array}{c}-0.059 \\
0.441 \\
\end{array}$ \\
\hline $\begin{array}{c}\text { Head Circ. gain } \\
\text { between } 0-12 \text { months }\end{array}$ & $\begin{array}{l}\mathrm{r} \\
\mathrm{p}\end{array}$ & $\begin{array}{c}-0.294 \\
0.004\end{array}$ & $\begin{array}{c}-0.123 \\
0.21\end{array}$ & $\begin{array}{c}-0.122 \\
0.106\end{array}$ & $\begin{array}{l}-0.208 \\
0.007\end{array}$ \\
\hline $\begin{array}{c}\text { Head Circ. gain } \\
\text { between 0-5 months }\end{array}$ & $\begin{array}{l}\mathrm{r} \\
\mathrm{p}\end{array}$ & $\begin{array}{c}-0.163 \\
0.103 \\
\end{array}$ & $\begin{array}{r}-0.179 \\
0.066 \\
\end{array}$ & $\begin{array}{l}-0.133 \\
0.082 \\
\end{array}$ & $\begin{array}{c}-0.196 \\
0.01 \\
\end{array}$ \\
\hline $\begin{array}{c}\text { Head Circ. gain } \\
\text { between 5-12 months }\end{array}$ & $\begin{array}{l}\mathrm{r} \\
\mathrm{p}\end{array}$ & $\begin{array}{c}-0.147 \\
0.133\end{array}$ & $\begin{array}{l}0.064 \\
0.501\end{array}$ & $\begin{array}{c}-0.001 \\
0.993\end{array}$ & $\begin{array}{c}-0.053 \\
0.491\end{array}$ \\
\hline
\end{tabular}

Data summarize 100 datasets in which any missing data were imputed using multiple imputation as described in detail in the Methods section and the Online Supplementary Appendix. Infection was coded as "no infection=0" and "occurrence of infection=1'; Season was coded as "dry season (November-June)=0" and "wet season (July-October)=1"; Sex was coded as "female=0" and "male=1"; Head Circ.: head circumference. "r" denotes the Pearson correlation coefficient. Significance level is highlighted with blue shading. Dark blue: $P<0.001$; mid-blue: $P<0.01$; light blue: $P<0.05$. 
the hierarchy of factors associating with hepcidin and ferritin concentrations at five and 12 months. In these models, higher weight gain since birth remained a significant independent predictor of reduced hepcidin at five months of age in both cohorts (Table 3), and at 12 months in VPM (Table 4), irrespective of birthweight; however, weight change did not associate with ferritin concentration in these analyses. At 12 months of age, hepcidin was positively associated with CRP and season and inversely associated with sTfR, while at both time points and in each cohort we found significant inverse associations of ferritin with sTfR (Tables 3 and 4).

Together, these analyses not only highlight associations of hepcidin with markers of erythropoietic drive, inflammation and season that align with previous observations in older African pre-school children, ${ }^{21}$ but also reveal consistent evidence that prior weight gain predicts hepcidin (although not ferritin) at key time points across these infant populations, irrespective of birthweight and especially in earlier infancy.

Factors predicting changes in hepcidin and ferritin over time within infants: Iongitudinal analysis

We then utilized the longitudinal data, fitting fixed effects models to examine how changes over time in timevariant parameters (sTfR, CRP, plasma iron, infections, season, weaning status and growth) predicted changes over time in hepcidin and ferritin within infants. Fixed effects models eliminate confounding caused by any timeinvariant characteristic, measured or unmeasured, and
A

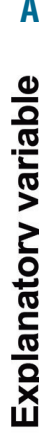

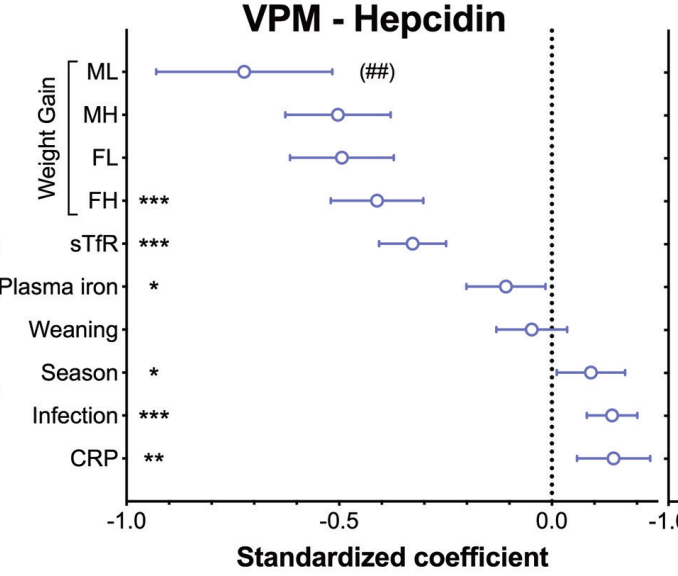

B

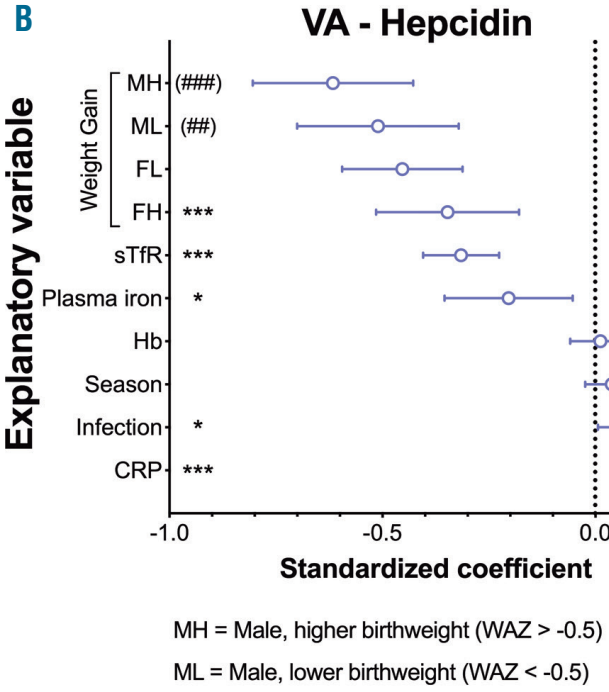

VPM - Ferritin

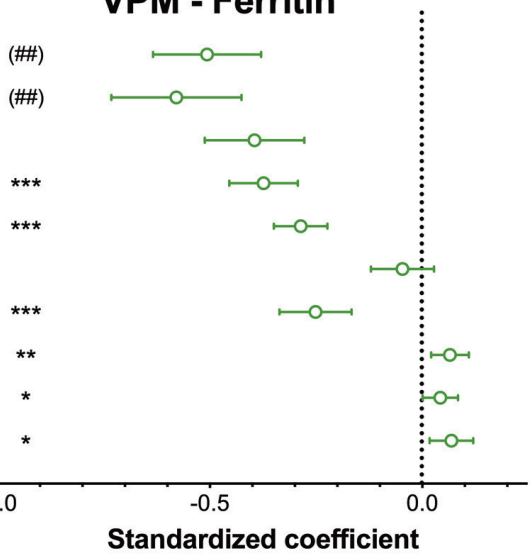

VA - Ferritin

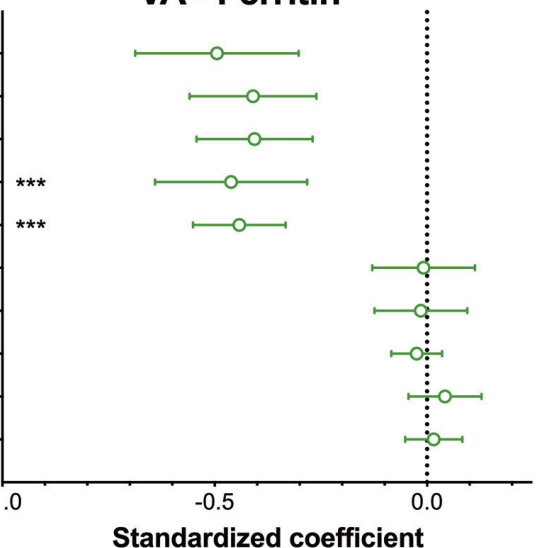

$\mathrm{FH}=$ Female, higher birthweight $(\mathrm{WAZ}>-0.5)$

$\mathrm{FL}=$ Female, lower birthweight $(\mathrm{WAZ}<-0.5)$

Figure 2. The relative influence of time-variant factors on changes in hepcidin and ferritin over time during the first year of life in Gambian infants: standardized Forest plots summarizing fixed effect models. Plots depict how a change of one standard deviation of an explanatory variable over time induces a change in standard deviation of outcome variables hepcidin (left panels) and ferritin (right panels) over time within a child in (A) the VPM cohort and (B) the VA cohort. Outcome variables are modeled simultaneously as "seemingly unrelated variables" to account for hepcidin/ferritin correlation, and data represent the pooled analysis of 100 datasets in which any missing data were imputed by multiple imputation, combined using Rubin's combination rules, as described in detail in the Online Supplementary Methods. Weaning was defined as the first recorded occurrence of any type of feeding other than exclusive breastfeeding. sTfR: soluble transferrin receptor; CRP: Creactive Protein; Hb: hemoglobin. The wet season was classified as July-October. Plots depict standardized coefficients with $95 \%$ Confidence Intervals. * $P<0.05$; $* * P<0.01 ; * * * P<0.001$. Interactions of weight change with birthweight group [above or below World Health Organization weight-for-age Z-score (WAZ) of -0.5 , i.e. close to the median observed across these two cohorts] and sex were modeled. $\# P<0.05$; \#\#P<0.01; \#\#\#P<0.001; respectively, for differences in the coefficients for weight change with respect to higher birthweight females as the reference group. Unstandardized and standardized coefficients are given in Table 5; equivalent analysis based on the dataset prior to multiple imputation is given in Online Supplementary Table S5. MH: higher birthweight males; ML: lower birthweight males; FH: higher birthweight females; FL: lower birthweight females; VPM: Vaccination and Paediatric Microbiome study; VA: a vitamin A supplementation randomized controlled trial. ${ }^{22}$ 
enable estimation of within-child effects, contrasting the above cross-sectional models. Moreover, standardizing coefficients allows comparison of the relative effect sizes of explanatory variables on outcome variables (Tables 5 and 6 and Figure 2).

Infection and increases in CRP over time associated with increasing hepcidin, while rising sTfR predicted hepcidin decline within infants, suggesting the models captured effects on hepcidin in expected directions. Increased plasma iron over time associated with decreased hepcidin in both cohorts. In the VPM dataset, the transition from dry to wet season, when infections are more prevalent, also associated with increased hepcidin (Table 5 and Figure 2A).

However, consistent with the cross-sectional (i.e. between-infant) analyses, the dynamic predictor of hepcidin decline that had the largest effect size in fixed effects models (i.e. within-infant) in both cohorts was weight gain (Tables 5 and 6 and Figure 2). The effect of weight gain on hepcidin suppression was highly significant in all groups of infants but was most pronounced in males: that is, a given increase in weight had a stronger suppressive effect on hepcidin over time in males (especially those born in the lower birthweight group in VPM) than in females. Weight gain also significantly predicted ferritin decline in both cohorts (in contrast to the multivariate cross-sectional analyses at 5 and 12 months). The effect of weight gain on ferritin decline, like hepcidin, was larger in males in the VPM cohort (Table 5 and Figure 2A) although no sex difference on ferritin was observed in the VA cohort.

\section{Discussion}

Hepcidin is the key regulator of iron absorption and dictates whether absorbed iron is sequestered or made available in the circulation..$^{10}$ Understanding how hepcidin is regulated is therefore vital in understanding the differential drivers of iron status, and how and whether iron interventions aimed at combating ID might be effectively targeted. ${ }^{6}$ Here, we have taken advantage of serial sampling of infants from two Gambian cohorts to describe changes in hepcidin and ferritin levels during the first year of life, and to examine how they are influenced by different factors using both cross-sectional and time series analysis.

Table 3. Cross-sectional multivariate associations between hepcidin, ferritin and explanatory variables in infants at five months of age.

\begin{tabular}{|c|c|c|c|}
\hline A.VPM - 5 months - N=114 & Coefficient & $95 \%$ CI & $P$ \\
\hline \multicolumn{4}{|l|}{ Outcome variable: HEPCIDIN } \\
\hline Plasma iron, $\mu \mathrm{mol} / \mathrm{L}$ & -0.127 & $-0.252--0.002$ & 0.047 \\
\hline sTfR, mg/L & -0.641 & $-1.592-0.310$ & 0.186 \\
\hline CRP, mg/L & 0.218 & $-0.076-0.513$ & 0.145 \\
\hline Infection in last 4 weeks & 0.103 & $-0.144-0.350$ & 0.412 \\
\hline Sex & -0.050 & $-0.238-0.139$ & 0.606 \\
\hline Weight change (0-5 months), kg & -5.543 & $-8.786--2.300$ & 0.001 \\
\hline Season & 0.247 & $0.080-0.413$ & 0.004 \\
\hline \multicolumn{4}{|l|}{ Outcome variable: FERRITIN } \\
\hline sTfR, mg/L & -1.076 & $-2.11--0.039$ & 0.042 \\
\hline CRP, mg/L & 0.265 & $-0.043-0.574$ & 0.092 \\
\hline Sex & -0.251 & $-0.463--0.039$ & 0.020 \\
\hline Weight change (0-5 months), kg & -1.828 & $-0.463-1.607$ & 0.297 \\
\hline B. VA - 5 months - N=193 & Coefficient & $95 \%$ CI & $\boldsymbol{P}$ \\
\hline \multicolumn{4}{|l|}{ Outcome variable: HEPCIDIN } \\
\hline sTfR, mg/L & -0.700 & $-1.362--0.039$ & 0.039 \\
\hline CRP, mg/L & 0.148 & $0.033-0.263$ & 0.012 \\
\hline Infection in last 4 weeks & -0.054 & $-0.283-0.175$ & 0.645 \\
\hline Weight change (0-5 months), kg & -3.307 & $-6.069--0.545$ & 0.019 \\
\hline \multicolumn{4}{|l|}{ Outcome variable: FERRITIN } \\
\hline Plasma iron, $\mu \mathrm{mol} / \mathrm{L}$ & 0.057 & $-0.129-0.244$ & 0.545 \\
\hline sTfR, mg/L & -1.127 & $-1.953--0.301$ & 0.008 \\
\hline CRP, mg/L & -0.031 & $-0.175-0.113$ & 0.670 \\
\hline $\mathrm{Hb}, \mathrm{g} / \mathrm{dL}$ & 1.627 & $-1.000-4.253$ & 0.224 \\
\hline Sex & -0.066 & $-0.347-0.216$ & 0.648 \\
\hline Weight change (0-5 months), kg & -0.173 & $-4.364-4.018$ & 0.935 \\
\hline
\end{tabular}

The outcome variables hepcidin and ferritin were handled using Seemingly Unrelated Regressions, with World Health Organization birth weight-for-age Z-score used as an instrument for weight change. Only variables with $P<0.2$ in univariate regressions were included in multivariable models, omitting correlated indices as described in the Methods section. Data summarise 100 datasets in which any missing data were imputed using multiple imputation as described in detail in the Methods section and the Online Supplementary Appendix. Infection was coded as "no infection=0" and "occurrence of infection=1'; Season was coded as "dry season (November-June)=0" and "wet season (July-October)=1"; Sex was coded as "female=0" and "male=1". 
We demonstrate that a marked decline in iron status through infancy is reflected by progressive reduction in hepcidin concentrations, and that while hepcidin appears to be regulated by similar factors in infants, older children and adults, weight gain is the most prominent dynamic predictor of the extent of hepcidin decline in infants. The data highlight post-natal growth as being strongly associated with the onset of iron depletion, and potentially associated with downstream sequelae, including anemia in vulnerable populations of infants.

The decline of hepcidin during infancy observed in both cohorts is consistent with data from previous smaller studies in Zimbabwean and Kenyan infants, ${ }^{33-35}$ which likewise described more pronounced effects in males. The parallel declines in hepcidin and ferritin, at a time when inflammation (which would be expected to increase both markers) is rising, illustrate the rapidity and severity of the onset of ID. Contrasting the dynamics of hepcidin in African infants, hepcidin levels were reported as stable during the first year in Europeans, ${ }^{36,37}$ presumably reflecting higher iron provision in weaning diets and lower cumulative exposure to infection and consequent inflammation. Human breastmilk has a low iron content ${ }^{5}$ and
Gambian babies are predominantly breastfed for the first 6 months and beyond. ${ }^{38}$ Moreover, as our data demonstrate, inflammation, infection and the season when infections are more prevalent were all associated with relatively raised hepcidin concentrations, even in cases of low iron status, potentially contributing to iron depletion in African infants.

One notable observation was the dramatic depletion of plasma iron between birth and 5 months of age to concentrations well below the previously described typical levels in infancy; ${ }^{31}$ these low levels persisted throughout the remainder of the first year. Availability of plasma iron is critical for supplying iron-demanding tissues. During infancy, iron is essential for erythropoiesis, but is also required by the developing brain which is a key consumer of iron, ${ }^{4}$ as well as by muscle and for tissue accretion. ${ }^{39}$ The proportional iron demands of these tissues are not constant through the first year of life: for example, erythropoietin levels and erythropoietic output are relatively low in neonates, ${ }^{32}$ despite early infancy being a period of rapid growth. Effective adaptive immunity, critical in LMIC infants, also requires iron; this is demonstrated by the recent discovery that a mutation in the Tfre gene

Table 4. Cross-sectional multivariate associations between hepcidin, ferritin and explanatory variables in infants at five months of age.

\begin{tabular}{|c|c|c|c|}
\hline A.VPM - 12 months - N=114 & Coefficient & $95 \%$ Cl & $\boldsymbol{P}$ \\
\hline \multicolumn{4}{|l|}{ Outcome variable: HEPCIDIN } \\
\hline sTfR, mg/L & -1.708 & $-2.568--0.849$ & $<0.001$ \\
\hline CRP, mg/L & 0.221 & $0.100-0.342$ & $<0.001$ \\
\hline Infection in last 4 weeks & 0.167 & $-0.068-0.401$ & 0.163 \\
\hline Weight change (0-12 months), kg & -2.833 & $-5.583-0.082$ & 0.044 \\
\hline Season & 0.343 & $0.104-0.582$ & 0.005 \\
\hline \multicolumn{4}{|l|}{ FERRITIN } \\
\hline sTfR, mg/L & -1.200 & $-2.225--0.175$ & 0.022 \\
\hline CRP, mg/L & 0.170 & $0.001-0.339$ & 0.049 \\
\hline Infection in last 4 weeks & 0.223 & $-0.089-0.537$ & 0.161 \\
\hline Sex & -0.247 & $-0.535-0.040$ & 0.091 \\
\hline B.VA - 12 months - N=193 & Cocfficient & $95 \%$ Cl & $P$ \\
\hline \multicolumn{4}{|l|}{ Outcome variable: HEPCIDIN } \\
\hline sTfR, mg/L & -1.191 & $-1.870--0.511$ & 0.001 \\
\hline CRP, mg/L & 0.163 & $0.040-0.286$ & 0.009 \\
\hline $\mathrm{Hb}, \mathrm{g} / \mathrm{dL}$ & 0.330 & $-1.784-2.443$ & 0.760 \\
\hline Sex & -0.287 & $-0.485--0.089$ & 0.005 \\
\hline Weight change (0-12 months), kg & -1.362 & $-4.298-1.574$ & 0.363 \\
\hline Season & 0.267 & $0.081-0.453$ & 0.005 \\
\hline \multicolumn{4}{|l|}{ Outcome variable: FERRITIN } \\
\hline sTfR, mg/L & -1.450 & $-2.095--0.805$ & $<0.001$ \\
\hline CRP, mg/L & 0.109 & $-0.016-0.234$ & 0.087 \\
\hline $\mathrm{Hb}, \mathrm{g} / \mathrm{dL}$ & 0.275 & $-1.844-2.395$ & 0.799 \\
\hline Sex & -0.055 & $-0.243-0.132$ & 0.562 \\
\hline Weight change (0-12 months), kg & -1.325 & $-4.168-1.518$ & 0.361 \\
\hline Season & 0.112 & $-0.077-0.301$ & 0.247 \\
\hline
\end{tabular}

The outcome variables hepcidin and ferritin were handled using Seemingly Unrelated Regressions, with World Health Organization birth weight-for-age Z-score used as an instrument for weight change. Only variables with $P<0.2$ in univariate regressions were included in multivariable models, omitting correlated indices as described in the Methods section. Data summarize 100 datasets in which any missing data were imputed using multiple imputation as described in detail in the Methods section and the Online Supplementary Appendix. Infection was coded as "no infection=0" and "occurrence of infection=1'; Season was coded as "dry season (November-June)=0" and "wet season (July-October)=1"; Sex was coded as "female $=0$ " and "male $=1$ ". 
(encoding transferrin receptor 1 , TfR1), which abrogated lymphocyte iron acquisition, was the cause of fatal combined immunodeficiency due to an inability to protect against infections. ${ }^{40}$ Thus, it is conceivable that low plasma iron availability may similarly impair adaptive immunity. The longitudinal analyses paradoxically suggested that changes in plasma iron inversely predicted changes in hepcidin; the reason for this is unclear, but could be driven by events in the first two months, when serum iron and hepcidin appear to differ most in their kinetics.

Soluble transferrin receptor is frequently used as a biomarker of tissue iron demand, and is typically associated with erythropoiesis. ${ }^{41}$ Concentrations of sTfR fell between birth and two months of age in both cohorts, presumably reflecting low erythropoietic demand at this point consequent upon the decline of the high birth hemoglobin concentration and recycling of its iron; however, sTfR concentrations were raised by 12 months of age, especially in males. By this time, elevated sTfR strongly associated with suppressed hepcidin, and fixed effects modeling, demonstrated how increases in sTfR within an infant over time predicted hepcidin reduction (overcoming the hepcidin-stimulatory effect of inflammation). Erythropoietic drive can suppress liver hepcidin production through activity of the recently characterized erythroblast-derived hormone erythroferrone, liberating iron to meet erythropoietic demands. ${ }^{18}$ Erythroferrone assays were not available at the time of this analysis, but it will be important to investigate its role during infancy, especially in LMIC settings. In addition, our cross-sectional and longitudinal analyses both also revealed weight gain to be strongly associated with declining hepcidin during infancy. Tissue accretion and erythropoietic expansion are widely acknowledged as consumers of iron in infancy, yet variability in growth rate within and between infants is less frequently considered to be a risk factor for earlier onset of iron depletion and deficiency in infancy than other risk factors (such as premature birth, early cord clamping, low birthweight or early consumption of cow's milk). ${ }^{6,9}$ In univariable analysis, lower birthweight did correlate as expected with reduced hepcidin at five months in both cohorts, yet there was more consistent evidence of a relationship between antecedent growth and hepcidin (noting that there was no such relationship of hepcidin or ferritin with subsequent weight gain); moreover, in multivariate cross-sectional models, prior weight gain remained significantly inversely associated with hepcidin, irrespective of birthweight. Our longitudinal fixed effects models added strength to these observations, with more rapid weight gain predicting a more profound decline in hepcidin over

Table 5. The relative influence of time-variant factors on changes in hepcidin and ferritin over time during the first year of life in Gambian infants: fixed effect models - VPM cohort.

\begin{tabular}{|c|c|c|c|c|c|}
\hline Variable & $\begin{array}{c}\text { Coefficient } \\
\text { (unstandardized) }\end{array}$ & $\begin{array}{c}95 \% \text { CI } \\
\text { (unstandardized) }\end{array}$ & $\begin{array}{c}\text { Coefficient } \\
\text { (standardized) }\end{array}$ & $\begin{array}{c}95 \% \text { CI } \\
\text { (standardized) }\end{array}$ & $\boldsymbol{P}$ \\
\hline \multicolumn{6}{|l|}{ Outcome variable: HEPCIDIN } \\
\hline Season & 0.106 & $0.013-0.200$ & 0.092 & $0.011-0.172$ & 0.026 \\
\hline Infection in last 4 weeks & 0.207 & $0.119-0.294$ & 0.141 & $0.081-0.202$ & $<0.001$ \\
\hline Weaning & -0.060 & $-0.165-0.046$ & -0.047 & $-0.131-0.037$ & 0.265 \\
\hline Plasma iron, $\mu \mathrm{mol} / \mathrm{L}$ & -0.080 & $-0.150--0.010$ & -0.108 & $-0.202--0.015$ & 0.025 \\
\hline sTfR, mg/L & -0.974 & $-1.206--0.741$ & -0.328 & $-0.407--0.248$ & $<0.001$ \\
\hline CRP, mg/L & 0.105 & $0.042-0.168$ & 0.145 & $0.059-0.231$ & 0.001 \\
\hline Weight, kg & -1.402 & $-1.786--1.018$ & -0.411 & $-0.522--0.301$ & $<0.001$ \\
\hline lower birthweight females & -0.281 & $-0.687-0.125$ & -0.083 & $-0.202-0.037$ & 0.172 \\
\hline lower birthweight males & -1.064 & $-1.781--0.348$ & -0.312 & $-0.520--0.104$ & 0.005 \\
\hline higher birthweight males & -0.313 & $-0.628-0.002$ & -0.092 & $-0.184-0.000$ & 0.052 \\
\hline \multicolumn{6}{|l|}{ Outcome variable: FERRITIN } \\
\hline Season & 0.104 & $0.033-0.176$ & 0.065 & $0.020-0.110$ & 0.005 \\
\hline Infection in last 4 weeks & 0.085 & $-0.000-0.171$ & 0.042 & $-0.000-0.085$ & 0.050 \\
\hline Weaning & -0.438 & $-0.586--0.291$ & -0.251 & $-0.337--0.166$ & $<0.001$ \\
\hline Plasma iron, $\mu \mathrm{mol} / \mathrm{L}$ & -0.048 & $-0.124-0.028$ & -0.047 & $-0.121-0.028$ & 0.215 \\
\hline sTfR, mg/L & -1.176 & $-1.439--0.914$ & -0.286 & $-0.349--0.223$ & $<0.001$ \\
\hline CRP, mg/L & 0.069 & $0.017-0.120$ & 0.068 & $0.017-0.120$ & 0.010 \\
\hline Weight, kg & -1.760 & $-2.144--1.377$ & -0.374 & $-0.455--0.293$ & $<0.001$ \\
\hline lower birthweight females & -0.099 & $-0.559-0.361$ & -0.021 & $-0.119-0.077$ & 0.672 \\
\hline lower birthweight males & -0.626 & $-1.080--0.172$ & -0.133 & $-0.229--0.037$ & 0.007 \\
\hline higher birthweight males & -0.966 & $-1.560--0.371$ & -0.205 & $-0.331--0.079$ & 0.002 \\
\hline
\end{tabular}

Data represent the pooled analysis of 100 datasets in which any missing data were imputed by multiple imputation, combined using Rubin's combination rules, as described in detail in Online Supplementary Methods. Unstandardized coefficients indicate the effect of a unit change over time of an explanatory variable on changes over time within a child in the outcome variables hepcidin and ferritin, which were handled using seemingly unrelated regression to account for strong correlations between outcome variables. Standardized coefficients indicate the effect of a change of one standard deviation of an explanatory variable over time on standard deviation of outcome variables over time within a child. Infection was coded as "no infection=0" and "occurrence of infection=1"; Season was coded as "dry season (November-June)=0" and "wet season (JulyOctober) $=1$ "; Sex was coded as "female=0" and "male=1". Interactions of weight change with birthweight group (groups indicated in italics: above or below WHO weight-for-age z-score of -0.5) and sex were modeled with coefficients/ $P$-values representing differences for weight change relative to higher birthweight females as reference group. 
time. In the within-subject analyses, there was also a highly significant effect of weight gain on ferritin decline, apparently contrasting the cross-sectional models in which no association of ferritin with weight gain was found; this discrepancy likely reflects the better efficiency of analyzing data longitudinally.

The hepcidin-suppressive effect of rapid growth therefore warrants mechanistic evaluation. It may relate to known hepcidin-regulatory signals, such as decreased transferrin saturation and hepatic iron. Growth factors, especially insulin-like growth factor 1 (IGF-1), play important roles in infant growth and development; ${ }^{42}$ hepatocyte growth factor (HGF), epidermal growth factor (EGF), and platelet-derived growth factor $\mathrm{BB}$ (PDGF-BB) are able to down-regulate hepcidin transcription. ${ }^{43,44}$ These or related growth factors should, therefore, be considered as candidate contributors to hepcidin suppression during infancy. Furthermore, erythroferrone provides a precedent for an iron-demanding process, erythropoiesis, evolving to produce a hepcidin suppressive hormone to facilitate iron supply. Further consideration should be given to the extent to which decreasing transferrin saturation due to, or erythroferrone derived from, an expanding erythron accounts for the observed relationship between rapid growth and hepcidin suppression and iron depletion at different stages of infancy, compared to growth and development of other tissues such as muscle and brain. Whether non-erythroid iron-demanding tissues that grow rapidly during infancy similarly up-regulate erythroferrone itself or other, as yet undefined, signals should be investigated.

The proportional effect of weight gain on hepcidin was also more pronounced in males. This sex difference might reflect differences in hormonal regulation of hepcidin exacerbating effects of weight gain: for example, testosterone suppresses hepcidin in mice ${ }^{45}$ and humans, ${ }^{46}$ and is elevated in males during the 'mini-puberty' of early infancy. ${ }^{47}$

The availability of two well-sized cohorts providing longitudinal data provides a key strength of the analyses presented here, allowing investigation of factors affecting changes in hepcidin and ferritin within infants through the first year. Causal inference using longitudinal data faces two sources of confounding: time-variant confounding and time-invariant confounding. Unlike other regression models, fixed effects panel models control for any timeinvariant confounding, measured or unmeasured. Despite this benefit, our models are still unlikely to fully capture all potential time-variant explanatory variables, limiting inference of causation. Since our analyses were retrospec-

Table 6. The relative influence of time-variant factors on changes in hepcidin and ferritin over time during the first year of life in Gambian infants: fixed effect models - VA cohort.

\begin{tabular}{|c|c|c|c|c|c|}
\hline Variable & $\begin{array}{c}\text { Coefficient } \\
\text { (unstandardized) }\end{array}$ & $\begin{array}{c}95 \% \mathrm{CI} \\
\text { (unstandardized) }\end{array}$ & $\begin{array}{c}\text { Coefficient } \\
\text { (standardized) }\end{array}$ & $\begin{array}{c}95 \% \text { CI } \\
\text { (standardized) }\end{array}$ & $P$ \\
\hline \multicolumn{6}{|l|}{ Outcome variable:HEPCIDIN } \\
\hline Season & 0.063 & $-0.040-0.166$ & 0.038 & $-0.024-0.100$ & 0.231 \\
\hline Infection in last 4 weeks & 0.116 & $0.009-0.224$ & 0.072 & $0.005-0.140$ & 0.035 \\
\hline Plasma iron, $\mu \mathrm{mol} / \mathrm{L}$ & -0.194 & $-0.342--0.466$ & -0.204 & $-0.356--0.052$ & 0.009 \\
\hline sTfR, mg/L & -1.161 & $-1.513--0.809$ & -0.316 & $-0.406--0.225$ & $<0.001$ \\
\hline CRP, mg/L & 0.133 & $0.060-0.205$ & 0.160 & $0.073-0.246$ & $<0.001$ \\
\hline $\mathrm{Hb}, \mathrm{g} / \mathrm{dL}$ & 0.115 & $-0.610-0.840$ & 0.012 & $-0.061-0.084$ & 0.751 \\
\hline Weight, $\mathrm{kg}$ & -1.581 & $-2.342--0.819$ & -0.347 & $-0.516--0.179$ & $<0.001$ \\
\hline lower birthweight females & -0.484 & $-1.083-0.116$ & -0.106 & $-0.238-0.026$ & 0.112 \\
\hline ower birthweight males & -0.745 & $-1.229--0.260$ & -0.163 & $-0.270--0.057$ & 0.003 \\
\hline higher birthweight males & -1.226 & $-1.819--0.633$ & -0.269 & $-0.398--0.140$ & $<0.001$ \\
\hline \multicolumn{6}{|l|}{ Outcome variable: FERRITIN } \\
\hline Season & -0.044 & $-0.154-0.065$ & -0.024 & $-0.085-0.036$ & 0.425 \\
\hline Infection in last 4 weeks & 0.073 & $-0.078-0.225$ & 0.042 & $-0.045-0.129$ & 0.338 \\
\hline Plasma iron, $\mu \mathrm{mol} / \mathrm{L}$ & -0.008 & $-0.137-0.120$ & -0.008 & $-0.132-0.115$ & 0.895 \\
\hline sTfR, mg/L & -1.762 & $-2.205--1.319$ & -0.442 & $-0.552--0.332$ & $<0.001$ \\
\hline CRP, mg/L & 0.014 & $-0.048-0.076$ & 0.016 & $-0.053-0.084$ & 0.651 \\
\hline $\mathrm{Hb}, \mathrm{g} / \mathrm{dL}$ & -0.158 & $-1.354-1.037$ & -0.015 & $-0.126-0.096$ & 0.792 \\
\hline Weight, $\mathrm{kg}$ & -2.278 & $-3.165--1.391$ & -0.461 & $-0.641--0.281$ & $<0.001$ \\
\hline lower birthweight females & 0.273 & $-0.494-1.039$ & 0.055 & $-0.100-0.211$ & 0.481 \\
\hline lower birthweight males & 0.254 & $-0.606-1.115$ & 0.051 & $-0.122-0.225$ & 0.558 \\
\hline higher birthweight males & -0.164 & $-1.011-0.683$ & -0.033 & $-0.205-0.139$ & 0.700 \\
\hline
\end{tabular}

Data represent the pooled analysis of 100 datasets in which any missing data were imputed by multiple imputation, combined using Rubin's combination rules, as described in detail in Online Supplementary Methods. Unstandardized coefficients indicate the effect of a unit change over time of an explanatory variable on changes over time within a child in the outcome variables hepcidin and ferritin, which were handled using seemingly unrelated regression to account for strong correlations between outcome variables. Standardized coefficients indicate the effect of a change of one standard deviation of an explanatory variable over time on standard deviation of outcome variables over time within a child. Infection was coded as "no infection=0" and "occurrence of infection=1"; Season was coded as "dry season (November-June)=0" and "wet season (JulyOctober) $=1$ "; Sex was coded as "female=0" and "male=1". Interactions of weight change with birthweight group (groups indicated in italics: above or below WHO weight-for-age z-score of -0.5) and sex were modeled with coefficients/P-values representing differences for weight change relative to higher birthweight females as reference group. 
tive investigations of cohorts that had been enrolled for other purposes, certain desirable variables were unavailable: for example, hemoglobin data were not collected in VPM, and for both cohorts, we cannot exclude the possibility that participants took iron-containing supplements, breast-milk substitutes or fortified complementary diets during the study period since this information was not systematically collected. Furthermore, given the known impact of season on iron status in this region, ${ }^{21}$ it would have been desirable for enrollment to span at least one full year in each cohort. This was not the case in VPM, meaning the majority of VPM 12-month samples were taken in the dry season (Online Supplementary Table S2A), possibly explaining in part the apparent higher prevalence of ID in VPM at 12 months (Online Supplementary Table S3). Nevertheless, we believe our models are still of great value in characterizing predictors of hepcidin and ferritin decline in infancy.

Other limitations should also be considered. Self-reporting of infectious episodes may have poor sensitivity and specificity for actual infection. Plasma biomarkers of inflammation may only capture current or recent inflammatory insults; since previous inflammation may contribute to reduced iron status through chronically raised hepcidin, higher resolution tracking of inflammatory events between key time points would be desirable. Finally, whether the effects we describe are maintained in distinct LMIC infant populations, most notably regions with a high malarial burden, should be further investigated.

Universal iron interventions for LMIC infants have proven to be relatively ineffective in reducing the burden of anemia, partly because only a proportion of anemia is thought to be iron responsive. ${ }^{48}$ Iron absorption is facilitated in the presence of low hepcidin concentrations, but inhibited when hepcidin is raised (such as during infection/inflammation), potentially explaining why many infants respond poorly to iron interventions. ${ }^{20,49,50}$ Growth rate has previously been linked to reduced ferritin and iron deficiency, ${ }^{51-54}$ and has been shown to be predictive of hemoglobin response to iron supplementation; $;{ }^{55}$ hepcidin suppression during rapid growth likely explains the latter effect. Since rapid growth predicts greater hepcidin suppression, our data suggest that simple weight monitoring could enable identification of rapidly growing infants to whom oral iron might be advantageously targeted.

\section{Acknowledgments}

The authors would like to thank the study participants and their families, the field teams and laboratory staff. We thank Rita Wegmïller for overseeing laboratory analyses at the MRC Keneba field station and for helpful discussions. The original VA study was funded by the UK Medical Research Council (MRC) (see below).

\section{Funding}

The original VPM study was funded by the Bill \& Melinda Gates Foundation (BMGF). The current analyses were supported by BMGF (OPP 1055865) awarded to the MRC International Nutrition Group which is core-funded by MCA760-5QX00 from the MRC and the UK Department for International Development (DFID) under the MRC/DFID Concordat agreement. AEA and $H D$ receive core-funding through the MRC Human Immunology Unit, MRC Weatherall Institute of Molecular Medicine, University of Oxford (MC_UU_12010/3).

\section{References}

1. GBD-2016-Disease-and-Injury-Incidenceand-Prevalence-Collaborators. Global, regional, and national incidence, prevalence, and years lived with disability for 328 diseases and injuries for 195 countries, 1990-2016: a systematic analysis for the Global Burden of Disease Study 2016. Lancet. 2017;390(10100):1211-1259.

2. WHO. The global prevalence of anaemia in 2011. Geneva; 2015.

3. Georgieff MK. Long-term brain and behavioral consequences of early iron deficiency. Nutr Rev. 2011;69(Suppl 1):S43-S48.

4. Cusick SE, Georgieff MK. The Role of Nutrition in Brain Development: The Golden Opportunity of the "First 1000 Days". J Pediatr. 2016;175:16-21.

5. Lonnerdal B. Development of iron homeostasis in infants and young children. Am J Clin Nutr. 2017;106(Suppl 6):1575S-1580S.

6. Domellof M, Braegger C, Campoy C, et al. Iron requirements of infants and toddlers. J Pediatr Gastroenterol Nutr. 2014;58(1):119129.

7. Dewey KG, Chaparro CM. Session 4: Mineral metabolism and body composition iron status of breast-fed infants. Proc Nutr Soc. 2007:66(3):412-422

8. Ziegler EE, Nelson SE, Jeter JM. Iron stores of breastfed infants during the first year of life. Nutrients. 2014;6(5):2023-2034
9. Chaparro CM. Setting the stage for child health and development: prevention of iron deficiency in early infancy. J Nutr. 2008;138(12):2529-2533

10. Ganz T. Systemic iron homeostasis. Physiol Rev. 2013;93(4):1721-1741.

11. Nemeth E, Tuttle MS, Powelson J, et al. Hepcidin regulates cellular iron efflux by binding to ferroportin and inducing its internalization. 2004;306(5704):2090-2093

12. Drakesmith H, Prentice AM. Hepcidin and the iron-infection axis. Science. 2012;338(6108):768-772.

13. Arezes J, Jung G, Gabayan V, et al Hepcidin-induced hypoferremia is a critical host defense mechanism against the siderophilic bacterium Vibrio vulnificus. Cell Host Microbe. 2015;17(1):47-57.

14. De Falco L, Sanchez M, Silvestri L, et al. Iron refractory iron deficiency anemia. Haematologica. 2013;98(6):845-853.

15. Gwamaka M, Kurtis JD, Sorensen BE, et al. Iron deficiency protects against severe Plasmodium falciparum malaria and death in young children. Clin Infect Dis. 2012:54(8):1137-1144.

16. Jonker FA, Calis JC, van Hensbroek MB, et al. Iron status predicts malaria risk in Malawian preschool children. PLoS One. 2012;7(8):e42670

17. Muriuki JM, Mentzer AJ, Kimita W, et al. Iron Status and Associated Malaria Risk Among African Children. Clin Infect Dis.
2018 Sep 14. [Epub ahead of print]

18. Kautz L, Jung G, Valore EV, Rivella S, Nemeth E, Ganz T. Identification of erythroferrone as an erythroid regulator of iron metabolism. Nat Genet. 2014;46(7) 678-684.

19. Pasricha SR, Atkinson SH, Armitage AE, et al. Expression of the iron hormone hepcidin distinguishes different types of anemia in African children. Sci Transl Med. 2014;6(235):235re233.

20. Prentice AM, Doherty CP, Abrams SA, et al. Hepcidin is the major predictor of erythrocyte iron incorporation in anemic African children. Blood. 2012;119(8):19221928

21. Atkinson $\mathrm{SH}$, Armitage AE, Khandwala S, et al. Combinatorial effects of malaria season, iron deficiency, and inflammation determine plasma hepcidin concentration in African children. Blood. 2014; 123(21):3221-3229.

22. Darboe MK, Thurnham DI, Morgan G, et al. Effectiveness of an early supplementation scheme of high-dose vitamin A versus standard WHO protocol in Gambian mothers and infants: a randomised controlled trial. Lancet. 2007;369(9579):2088-2096.

23. Leroy JF. zscore06: Stata command for the calculation of anthropometric z-scores using the 2006 WHO child growth standards. 2011. Available from:https://econpapers.repec.org/software/bocbocode/ s457279.htm 
24. Graham JW. Missing data analysis: making it work in the real world. Annu Rev Psychol. 2009;60:549-576.

25. Sterne JA, White IR, Carlin JB, et al. Multiple imputation for missing data in epidemiological and clinical research: potential and pitfalls. BMJ. 2009;338:b2393.

26. van Burren S, Groothuis-Oudshoorn K. mice: Multivariate Imputation by Chained Equations in R. J Stat Softw. 2011;45(3):1-67.

27. Rubin DB. Multiple imputation for nonresponse in surveys John Wiley \& Sons., 2004.

28. Zellner A. An Efficient Method of Estimating Seemingly Unrelated Regressions and Tests for Aggregation Bias. J Am Stat Assoc. 1962;57(298):348-368.

29. Driscoll JC, Kraay AC. Consistent covariance matrix estimation with spatially dependent panel data. The Review of Economics and Statistics. 1998;80(4):849860.

30. Hoechle D. Robust standard errors for panel regressions with cross-sectional dependence. Stata Journal. 2007;7(3):281.

31. Ritchie RF, Palomaki GE, Neveux LM, Navolotskaia O, Ledue TB, Craig WY. Reference distributions for serum iron and transferrin saturation: a comparison of a large cohort to the world's literature. J Clin Lab Anal. 2002;16(5):246-252.

32. Finne PH, Halvorsen S. Regulation of erythropoiesis in the fetus and newborn. Arch Dis Child. 1972;47(255):683-687.

33. Mupfudze TG, Stoltzfus RJ, Rukobo S, et al. Hepcidin decreases over the first year of life in healthy African infants. $\mathrm{Br} \mathrm{J}$ Haematol. 2014;164(1):150-153.

34. Jaeggi T, Moretti D, Kvalsvig J, et al. Iron status and systemic inflammation, but not gut inflammation, strongly predict genderspecific concentrations of serum hepcidin in infants in rural Kenya. PLoS One. 2013; 8(2):e57513

35. Atkinson $\mathrm{SH}$, Uyoga SM, Armitage AE, et al. Malaria and Age Variably but Critically Control Hepcidin Throughout Childhood in Kenya. EBioMedicine. 2015;2(10):14781486.

36. Aranda N, Bedmar C, Arija V, et al. Serum hepcidin levels, iron status, and HFE gene alterations during the first year of life in healthy Spanish infants. Ann Hematol. 2018;97(6):1071-1080.

37. Berglund S, Lonnerdal B, Westrup B, Domellof M. Effects of iron supplementation on serum hepcidin and serum erythropoietin in low-birth-weight infants. Am J Clin Nutr. 2011;94(6):1553-1561.

38. Eriksen KG, Johnson W, Sonko B, Prentice AM, Darboe MK, Moore SE. Following the World Health Organization's Recommendation of Exclusive Breastfeeding to 6 Months of Age Does Not Impact the Growth of Rural Gambian Infants. J Nutr. 2017;147(2):248-255.

39. Beard JL. Iron biology in immune function, muscle metabolism and neuronal functioning. J Nutr. 2001;131(2S-2):568S-579S.

40. Jabara HH, Boyden SE, Chou J, et al. A missense mutation in TFRC, encoding transferrin receptor 1 , causes combined immunodeficiency. Nat Genet. 2016;48(1):74-78.

41. Pfeiffer CM, Looker AC. Laboratory methodologies for indicators of iron status: strengths, limitations, and analytical challenges. Am J Clin Nutr. 2017;106(Suppl 6): $1606 \mathrm{~S}-1614 \mathrm{~S}$.

42. Netchine I, Azzi S, Le Bouc Y, Savage MO. IGF1 molecular anomalies demonstrate its critical role in fetal, postnatal growth and brain development. Best Pract Res Clin Endocrinol Metab. 2011;25(1):181-190.

43. Goodnough JB, Ramos E, Nemeth E, Ganz $\mathrm{T}$. Inhibition of hepcidin transcription by growth factors. Hepatology. 2012; 56(1):291-299.

44. Sonnweber T, Nachbaur D, Schroll A, et al. Hypoxia induced downregulation of hepcidin is mediated by platelet derived growth factor BB. Gut. 2014;63(12):1951 1959.

45. Latour C, Kautz L, Besson-Fournier C, et al. Testosterone perturbs systemic iron balance through activation of epidermal growth factor receptor signaling in the liver and repression of hepcidin. Hepatology. 2014:59(2):683-694

46. Bachman E, Feng R, Travison $\mathrm{T}$, et al. Testosterone suppresses hepcidin in men: a potential mechanism for testosteroneinduced erythrocytosis. J Clin Endocrino Metab. 2010;95(10):4743-4747.

47. Forest MG, Sizonenko PC, Cathiard AM Bertrand J. Hypophyso-gonadal function in humans during the first year of life. 1. Evidence for testicular activity in early infancy. J Clin Invest. 1974;53(3):819-828.

48. Pasricha SR, Armitage AE, Prentice AM Drakesmith H. Reducing anaemia in low income countries: control of infection is essential. BMJ. 2018;362:k3165.

49. Cercamondi CI, Egli IM, Ahouandjinou E et al. Afebrile Plasmodium falciparum parasitemia decreases absorption of fortification iron but does not affect systemic iron utilization: a double stable-isotope study in young Beninese women. Am J Clin Nutr. 2010;92(6):1385-1392.

50. Moretti D, Goede JS, Zeder C, et al. Oral iron supplements increase hepcidin and decrease iron absorption from daily or twice-daily doses in iron-depleted young women. Blood. 2015;126(17):1981-1989.

51. Michaelsen KF, Milman N, Samuelson G. A longitudinal study of iron status in healthy Danish infants: effects of early iron status, growth velocity and dietary factors. Acta Paediatr. 1995;84(9):1035-1044

52. Thorsdottir I, Gunnarsson BS, Atladottir $\mathrm{H}$ Michaelsen KF, Palsson G. Iron status at 12 months of age -- effects of body size, growth and diet in a population with high birth weight. Eur J Clin Nutr. 2003;57(4):505-513.

53. Sherriff A, Emond A, Hawkins N, Golding J. Haemoglobin and ferritin concentrations in children aged 12 and 18 months ALSPAC Children in Focus Study Team. Arch Dis Child. 1999;80(2):153-157.

54. Yang Z, Lonnerdal B, Adu-Afarwuah S, et al. Prevalence and predictors of iron deficiency in fully breastfed infants at 6 mo of age: comparison of data from 6 studies. Am J Clin Nutr. 2009:89(5):1433-1440.

55. Domellof M, Dewey KG, Lonnerdal B, Cohen RJ, Hernell $O$. The diagnostic criteria for iron deficiency in infants should be reevaluated. J Nutr. 2002;132(12):3680 3686. 